\title{
Impact of postharvest dehydration process of winegrapes on mechanical and acoustic properties of the seeds and their relationship with flavanol extraction during simulated maceration
}

\author{
Susana Río Segade ${ }^{a, *, 1}$, Fabrizio Torchio ${ }^{\mathrm{b}, 1}$, Vincenzo Gerbi ${ }^{\mathrm{a}, \mathrm{d}}$, Natalia Quijada-Morín ${ }^{\mathrm{c}}$, \\ Ignacio García-Estévez ${ }^{c}$, Simone Giacosa a ${ }^{\text {a }}$ M. Teresa Escribano-Bailón ${ }^{\mathrm{c}}$, Luca Rolle ${ }^{\mathrm{a}, \mathrm{d}}$ \\ ${ }^{a}$ Università degli Studi di Torino, Dipartimento di Scienze Agrarie, Forestali e Alimentari, Largo Paolo Braccini 2, 10095 Grugliasco, TO, Italy \\ ${ }^{\mathrm{b}}$ Istituto di Enologia e Ingegneria Agro-Alimentare, Università Cattolica del Sacro Cuore, Via Emilia Parmense 84, 29122 Piacenza, Italy \\ ${ }^{\mathrm{c}}$ Grupo de Investigación en Polifenoles, Unidad de Nutrición y Bromatología, Facultad de Farmacia, Universidad de Salamanca, E-37007 Salamanca, Spain \\ ${ }^{\mathrm{d}}$ Consiglio Nazionale delle Ricerche, Istituto per la Protezione Sostenibile delle Piante, Unità Grugliasco, Largo Paolo Braccini 2,10095 Grugliasco, TO, Italy
}

\section{A R T I C L E I N F O}

Article history:

Received 9 September 2015

Received in revised form 14 December 2015

Accepted 16 December 2015

Available online 18 December 2015

\section{Keywords:}

Flavanol extraction

Instrumental texture analysis

Mechanical properties

Acoustic emission

Seeds

Postharvest dehydration process

Nebbiolo winegrapes

\begin{abstract}
A B S T R A C T
This study represents the first time that the extraction of phenolic compounds from the seeds is assessed from instrumental texture properties for dehydrated grapes. Nebbiolo winegrapes were postharvest dehydrated at $20^{\circ} \mathrm{C}$ and $41 \%$ relative humidity. During the dehydration process, sampling was performed at $15 \%, 30 \%, 45 \%$ and $60 \%$ weight loss. The extractable fraction and extractability of phenolic compounds from the seeds were determined after simulated maceration. The evolution of mechanical and acoustic attributes of intact seeds was also determined during grape dehydration to evaluate how these changes affected the extraction of phenolic compounds. The extractable content and extractability of monomeric flavanols and proanthocyanidins, as well as the galloylation percentage of flavanols, might be predicted easily and quickly from the mechanical and acoustic properties of intact seeds. This would help in decision-making on the optimal dehydration level of winegrapes and the best management of winemaking of dehydrated grapes.
\end{abstract}

(c) 2015 Elsevier Ltd. All rights reserved.

\section{Introduction}

The growing necessity of diversifying the wine products is promoting the use of dehydrated winegrapes to produce high quality special wines. Many famous sweet, reinforced and fortified wines are produced with grapes differently withered (Mencarelli \& Tonutti, 2013).

Postharvest dehydration induces significant metabolic changes that affect the physico-chemical characteristics of winegrapes (Nicoletti et al., 2013; Serratosa, Marquez, Moyano, Zea, \& Merida, 2014). The extension of the chemical changes mainly depends on the grape cultivar, maturity stage and cultural practices, but it can be partially modulated by the management of the dehydration process (Bonghi et al., 2012; Mencarelli et al., 2010; Nicoletti et al., 2013). The juice is concentrated within the berry due to water loss, and therefore the content of some components increases, specifically sugars and volatile compounds

\footnotetext{
* Corresponding author.

E-mail address: susana.riosegade@unito.it (S. Río Segade).

1 These authors contributed equally to the study.
}

(Chkaiban et al., 2007; Moreno et al., 2008). In the solid parts of the grape, anthocyanins and proanthocyanidins are affected by postharvest grape dehydration. These phenolic compounds are differently prone to hydrolysis and oxidation processes that occur simultaneously to the concentration effect (Bonghi et al., 2012; Rolle, Giacosa, Río Segade, et al., 2013; Serratosa, LopezToledano, Merida, \& Medina, 2008). Postharvest dehydration in chambers under controlled environmental conditions may ensure a greater protection of the phenolic fraction than widely used traditional dehydration techniques, such as sun drying, because the oxidation of these compounds slows down (Frangipane, Torresi, De Santis, \& Massantini, 2012). Nevertheless, the thermohygrometric conditions influence these responses to water loss (Mencarelli et al., 2010; Rolle, Giacosa, Río Segade, et al., 2013).

The grape seeds are a rich source of flavanols (Mattivi, Vrhovsek, Masuero, \& Trainotti, 2009) that are partially extracted during winemaking. The increased contribution of flavanols from the seeds to the total content in dehydrated grapes compared with that in fresh ones (Rolle, Giacosa, Río Segade, et al., 2013; Rolle, Torchio, Giacosa, \& Gerbi, 2009) could affect important sensory characteristics such as tannic intensity, astringency and bitterness (Ferrer-Gallego, 
García-Marino, Hernández-Hierro, Rivas-Gonzalo, \& EscribanoBailón, 2010). Nevertheless, few studies have been published on the effect of the dehydration process on the phenolic composition of the seeds (Centioni, Tiberi, Pietromarchi, Bellincontro, \& Mencarelli, 2014; Moreno et al., 2008; Rolle, Giacosa, Río Segade, et al., 2013; Rolle et al., 2009). These studies have highlighted an increase in the content of proanthocyanidins and low molecular weight flavanols, and a decrease in the mean degree of polymerization. In this context, it is important to take into account that no study has dealt with the effects of grape dehydration on the extractability of phenolic compounds from the seeds during maceration.

During grape ripening, the compositional and physical changes occurring in the seeds gradually reduce the ease for releasing flavanols. The oxidation of flavanols favors their increased association with cell wall components (Downey, Harvey, \& Robinson, 2003; Kennedy, Matthews, \& Waterhouse, 2000). The intensive lignification of the medium integument and the dehydration of the outer integument lead to seed hardening, which in turn could prevent flavanols from being extracted during maceration (Bautista-Ortín et al., 2012; Cadot, Miñana-Castelló, \& Chevalier, 2006). Instrumental mechanical properties measured during the compression test of grape seeds have been evaluated as possible predictors of the extractable content and extractability of phenolic compounds through ripening, but the correlations found were low (Rolle et al., 2012). Considering that this hardening is usually accompanied by changes in the acoustic properties (Rolle, Giacosa, Torchio, \& Río Segade, 2012), some instrumental acoustic parameters of winegrape seeds have been proposed as predictors of extractable phenolic compounds, because of their satisfactory predictive accuracy for quantitative or screening purposes (Rolle, Giacosa, Torchio, et al., 2013; Torchio et al., 2012). Therefore, instrumental texture analysis, which is a fast and economically effective analytical technique, provides physical-mechanical information directly related to the phenolic composition of the seeds. This technique could be an important tool for monitoring the mechanical changes that occur in the seeds during postharvest grape dehydration. Some studies have reported that seed hardness decreases and seed springiness increases during the on-vine drying process (Rolle et al., 2009). These physical changes and their relationship with the evolution of the phenolic composition during dehydration would help in decision-making on the optimal dehydration grade of winegrapes and the best management of winemaking in order to produce high quality wines.

Given that knowledge on the extraction of phenolic compounds from the seeds during maceration for dehydrated grapes is lacking, the aim of the present study was to evaluate the impact of the postharvest dehydration process under controlled thermohygrometric conditions on the extraction of flavanols from seeds during simulated maceration. The evolution of the mechanical and acoustic properties of intact seeds from Nebbiolo red winegrapes during postharvest dehydration was investigated also for the first time in this study. Finally, the relationships of the mechanical and acoustic parameters of the seeds with different dehydration grades and the extraction of different flavanol compounds after maceration were then established with prediction purposes. The study was carried out on Nebbiolo because it is an autochthonous variety used also for the production of a special Italian red dry wine (Sfursat) from partially dehydrated grapes (Nicoletti et al., 2013).

\section{Materials and methods}

\subsection{Grape samples and dehydration process}

In this study, whole bunches of red grape Vitis vinifera L. cv. Nebbiolo were harvested from various vines in a commercial vineyard located in Alba (Piedmont region, north-west Italy) in 2013. The bunches were visually inspected, and those berries with damaged skins were discarded. At least 500 berries were randomly selected from different positions in the bunch for fresh grape analysis. Afterwards, the bunches were divided in small clusters (3-5 berries), which were randomly distributed in several batches of about $2 \mathrm{~kg}$ of grape berries and placed in perforated boxes in a single layer. All batches were dehydrated at $20 \pm 2{ }^{\circ} \mathrm{C}$ and $41 \pm 5 \%$ relative humidity $(\mathrm{RH})$ in a thermohygrometrically controlled chamber during 49 days (Torchio et al., 2016). The grapes were sampled at $15 \%, 30 \%, 45 \%$ and $60 \%$ weight loss (WL). For each sampling point during dehydration, at least 700 berries were randomly selected for dehydrated grape analysis.

All fresh grape clusters were weighed before their introduction into the withering cell and during the dehydration process at different times using a technical balance (Gibertini E1700, Modena, Italy) inside the withering cell. The percentage of WL was calculated as [100 - (weight of dehydrated samples $\times 100 /$ weight of fresh sample)].

For each sample (fresh and differently dehydrated grapes), three sets of berries were randomly selected. The first set consisted of three replicates of approximately $100 \mathrm{~g}$ of berries, and each replicate was accurately weighed. All berry seeds of each replicate were manually and carefully separated from the pulp, weighed and used for determining phenolic compounds. In the second set, one seed per berry was separated and used for instrumental texture analysis with a total of 30 intact seeds for each test (Torchio et al., 2012). The third set was subdivided into two replicates of 100 berries and used for determining the standard physicochemical parameters in the grape juice obtained by manual crushing and centrifugation.

\subsection{Chemical analysis}

\subsubsection{Reagents and standards}

Solvents of HPLC-gradient grade and all other chemicals of analytical-reagent grade were purchased from Sigma (Milan, Italy). The solutions were prepared in deionized water produced by a Purelab Classic system (Elga Labwater, Marlow, United Kingdom). Among phenolic standards, gallic acid (as GA), (+)-catechin (as C), (-)-epicatechin (as EC) and (-)-epicatechin gallate (as ECG) were obtained from Sigma, and cyanidin chloride and procyanidins $B_{1}$ and $B_{2}$ were purchased from Extrasynthèse (Genay, France).

\subsubsection{Standard parameters}

In the juice obtained, total soluble solids (TSS) content ( ${ }^{\circ}$ Brix) was measured with an Atago $0-32^{\circ}$ Brix temperature compensating refractometer (Atago Corporation, Tokyo, Japan), $\mathrm{pH}$ was determined by potentiometry using an InoLab 730 pHmeter (WTW, Weilheim, Germany), and titratable acidity ( $\mathrm{g} \mathrm{L}^{-1}$ tartaric acid, as TA) was determined using the OIV method (Organisation Internationale de la Vigne et du Vin, 2008).

\subsubsection{Extraction and determination of phenolic compounds}

All berry seeds belonging to each of the three replicates were immediately immersed into $100 \mathrm{~mL}$ of a buffer solution of $\mathrm{pH} 3.2$ containing $5 \mathrm{~g} \mathrm{~L}^{-1}$ tartaric acid and $100 \mathrm{mg} \mathrm{L}^{-1}$ sodium metabisulphite, under nitrogen atmosphere and slowly stirred for $15 \mathrm{~min}$ a day. For the first four days of maceration, ethanol was added daily to this solution at a dose of $3 \% \mathrm{v} / \mathrm{v}$ to simulate the fermentation/ maceration step. After reaching a final content of $12 \% \mathrm{v} / \mathrm{v}$ ethanol, the seeds were maintained at $30^{\circ} \mathrm{C}$ for another twelve days (Rolle, Giacosa, Torchio, et al., 2013). During maceration, small solution aliquots were taken daily for monitoring the extraction kinetics of phenolic compounds by measuring absorbance at $280 \mathrm{~nm}$ (as $A_{280}$ ). Once maceration was completed, the solution was 
completely taken and used for determining extracted seed phenolic compounds during simulated winemaking. The residual seeds were extracted three times into $20 \mathrm{~mL}$ of a $70 \% \mathrm{v} / \mathrm{v}$ acetone in water solution at $25^{\circ} \mathrm{C}$ for one day. This solution was used for determining non-extracted seed phenolic compounds (BautistaOrtín et al., 2012; Kennedy \& Jones, 2001). The extractability (\%) was also estimated as the (extracted compounds)/(extracted + non-extracted compounds) ratio. The extract was concentrated by evaporation to dryness under reduced pressure at $35^{\circ} \mathrm{C}$ and redissolved in $20 \mathrm{~mL}$ of methanol.

Spectrophotometric methods were used to determine $A_{280}$ $\left(\mathrm{kg}^{-1}\right.$ grape or $\mathrm{g}^{-1}$ seed), total phenols ( $\mathrm{mg}(+)$-catechin $\mathrm{kg}^{-1}$ grape or $\mathrm{g}^{-1}$ seed, as TP), total flavonoids ( $\mathrm{mg}(+)$-catechin $\mathrm{kg}^{-1}$ grape or $\mathrm{g}^{-1}$ seed, as TF), proanthocyanidins ( $\mathrm{mg}$ cyanidin chloride $\mathrm{kg}^{-1}$ grape or $\mathrm{g}^{-1}$ seed, as PRO) and flavanols reactive to vanillin (mg (+)-catechin $\mathrm{kg}^{-1}$ grape or $\mathrm{g}^{-1}$ seed, as FRV) (Rolle, Torchio, Giacosa, et al., 2012). A UV-1800 spectrophotometer (Shimazdu Corporation, Kyoto, Japan) was used.

Individual flavanols were determined by liquid chromatography before and after acid-catalyzed degradation of polymeric proanthocyanidins in the presence of phloroglucinol. Phloroglucinolysis of the seed extracts was carried out according to the method proposed by Kennedy and Jones (2001) and slightly modified by Torchio, Río Segade, Giacosa, Gerbi, and Rolle (2013). $1 \mathrm{~mL}$ of diluted seed extract was dealcoholized by evaporation to dryness under reduced pressure at $35^{\circ} \mathrm{C}$. Thereafter, the residue was redissolved in $0.5 \mathrm{~mL}$ phloroglucinol reagent consisting of $50 \mathrm{~g} \mathrm{~L}^{-1}$ phloroglucinol and $10 \mathrm{~g} \mathrm{~L}^{-1}$ ascorbic acid in methanol containing $0.1 \mathrm{~mol} \mathrm{~L}^{-1}$ hydrochloric acid, and they were allowed to react for $20 \mathrm{~min}$ at $50^{\circ} \mathrm{C}$. The reaction was stopped with addition of $0.5 \mathrm{~mL}$ of $200 \mathrm{mM}$ aqueous sodium acetate. The final extracts (taken before and after phloroglucinolysis) were filtered and immediately injected into a HPLC-DAD system.

The determination of gallic acid and individual flavanols was performed by HPLC-DAD using chromatographic conditions previously reported in the literature (Kennedy \& Jones, 2001). The chromatographic separations were carried out at $25^{\circ} \mathrm{C}$ on a LiChroCART analytical column $(250 \mathrm{~mm} \times 4 \mathrm{~mm}$ i.d.) purchased from Merck (Darmstadt, Germany), which was packed with LiChrospher 100 RP-18 $(5 \mu \mathrm{m})$ particles supplied by Alltech (Deerfield, IL, USA). The mobile phases consisted of $A=1 \%$ aqueous acetic acid; $\mathrm{B}=$ methanol, working at a flow-rate of $0.8 \mathrm{~mL} \mathrm{~min}^{-1}$. After the identification, the contents of individual gallic acid, monomeric flavanols (C, EC and ECG) and dimeric flavanols (procyanidins $\mathrm{B}_{1}$ and $B_{2}$ ) were quantified in $\mathrm{mg} \mathrm{kg}^{-1}$ grape or $\mathrm{g}^{-1}$ seed. The mean degree of polymerization (as $\mathrm{mDP}$ ) was calculated as the molar ratio of the sum of all flavanol units produced by phloroglucinolysis (phloroglucinol adducts plus monomers) to the sum of monomeric flavanols. The percentage of galloylation (as $G$ ) was calculated as the ratio of the sum of galloylated flavanols to the sum of all flavanols. All analyses of each replicate were performed in duplicate. According to a repeatability study performed by Mattivi et al. (2009), a total number of six replicates involving both sampling and analysis is adequate for the flavanol determination in the seeds.

\subsection{Instrumental texture analysis}

The mechanical properties of the intact seeds were determined by a compression test using a Universal Testing Machine TA.XTplus texture analyzer (Stable Micro Systems, Godalming, Surrey, England) equipped with a HDP/90 platform, a P/35 probe and a $50 \mathrm{~kg}$ load cell (Rolle, Giacosa, Torchio, et al., 2013; Torchio et al., 2012). Each of the thirty intact grape seeds was individually compressed in the equatorial position, and the following instrumental mechanical parameters were measured or calculated (Torchio et al., 2012): seed break force ( $\mathrm{N}$, as $F_{s}$ ), seed break energy (mJ, as $\left.W_{s}\right)$, seed Young's modulus of elasticity $\left(\mathrm{N} \mathrm{mm}^{-1}\right.$, as $\left.E_{s}\right)$, and seed deformation index $\left(\%\right.$, as $\left.\mathrm{DI}_{\mathrm{s}}\right)$. This last index was calculated as the distance of the seed break point/seed height $\times 100$.

The acoustic emission produced during the compression test was measured using an acoustic envelope detector (Stable Micro Systems) equipped with a $12.7 \mathrm{~mm}$ diameter Brüel and Kjær 4188-A-021 microphone (Nærum, Germany) (Rolle, Giacosa, Torchio, et al., 2013; Torchio et al., 2012). The microphone was positioned at a $20 \mathrm{~mm}$ distance from the sample at an angle of $45^{\circ}$ and connected to the texture analyzer. The recording of the acoustic emission produced was carried out at two different instrumental gain values ( 0 and $24 \mathrm{~dB}$ ). The following instrumental acoustic parameters were measured (Rolle, Giacosa, Torchio, et al., 2013; Torchio et al., 2012): acoustic pressure level at the breakage $(\mathrm{dB})$ and maximum acoustic pressure level $(\mathrm{dB})$ at gain 0 , and acoustic energy ( $\mathrm{dB} \times \mathrm{mm}$, as $\mathrm{AE}$ ), linear distance (adimensional, as LD), number of acoustic peaks higher than $15 \mathrm{~dB}$ (adimensional, as $N_{\mathrm{pk}>15 \mathrm{~dB}}$ ), number of acoustic peaks higher than $5 \mathrm{~dB}$ (adimensional, as $N_{\mathrm{pk}>5 \mathrm{~dB}}$ ), average acoustic pressure level for peaks with threshold higher than $15 \mathrm{~dB}\left(\mathrm{~dB}\right.$, as $\left.\mathrm{AV}_{\mathrm{pk}>15 \mathrm{~dB}}\right)$ and average acoustic pressure level for peaks with threshold higher than $5 \mathrm{~dB}\left(\mathrm{~dB}\right.$, as $\left.A V_{\mathrm{pk}>5 \mathrm{~dB}}\right)$ at gain 24 . With the exception of the two first parameters, all remaining ones were separately determined before and after breaking, and the total value $(t)$ during the compression test was calculated. All data acquisitions were made at 500 points per second for the simultaneous mechanical and acoustic measurements using the Texture Exponent software package (Stable Micro Systems).

\subsection{Statistical analysis}

Statistical analyses were performed using the SPSS Statistics software package version 19.0 (IBM Corporation, Armonk, NY, USA). The Tukey-b test at $p<0.05$ was used to establish significant differences by one-way analysis of variance (ANOVA). Pearson's correlation coefficients were calculated to determine significant relationships of the mechanical and acoustic parameters with the phenolic composition of the seeds.

\section{Results and discussion}

\subsection{Dehydration kinetics and standard parameters of grapes}

The dehydration kinetics of Nebbiolo winegrapes was linear during the first sixteen days reaching a WL of $28 \%$ (Fig. S1). This corresponds to a daily average WL of $1.75 \%$, which was higher than that reached using $20^{\circ} \mathrm{C}$ and $60 \% \mathrm{RH}$ conditions in a previously published work, where the same grape variety achieved in the same period a daily average WL of $1.25 \%$ (Nicoletti et al., 2013). The moisture diffusion coefficient decreases with increasing $\mathrm{RH}$ (Barbanti, Mora, Ferrarini, Tornielli, \& Cipriani, 2008). In the present study, the dehydration rate was then lower, and the global dehydration kinetics fitted to a polynomial function $\left(y=-0.012 x^{2}+1.644 x+3.664, R^{2}=0.997\right.$, where $x$ are dehydration days and $y$ is WL (\%); final daily average WL of $1.15 \%$ ).

The standard parameters of Nebbiolo winegrapes were determined at different WL values during the dehydration process (Table 1). The TSS content increased significantly with increasing the WL value, because the juice components were concentrated as dehydration progresses. However, the concentration effect affected only the TA value when the berry weight decreased strongly $(60 \%$ $\mathrm{WL}$ ). During grape dehydration, cations are also concentrated and malic acid decreases, which could compensate the concentration effect of acids for WL values lower than $60 \%$. The significant increase 
in the $\mathrm{pH}$ values evidenced the depletion of organic acids such as malic acid (Rolle, Giacosa, Río Segade, et al., 2013; Santonico, Bellincontro, De Santis, Di Natale, \& Mencarelli, 2010).

\subsection{Extractable content of phenolic compounds from seeds}

For the berries sampled at different WL values, the extraction kinetics of phenolic compounds from Nebbiolo seeds during simulated maceration was monitored daily by means of $A_{280}$ (Fig. S2). The release of phenolic compounds was faster and higher as berry dehydration progressed. The global extraction kinetics fitted to a polynomial function according to the following equations: $y=-0.115 x^{2}+3.738 x-2.064, \quad R^{2}=0.997$ for fresh berries; $y=-0.166 x^{2}+5.025 x-0.830, R^{2}=0.998$ for dehydrated berries at $15 \% \mathrm{WL} ; y=-0.128 x^{2}+4.407 x+0.261, R^{2}=1.000$ for dehydrated berries at $30 \% \mathrm{WL} ; y=-0.241 x^{2}+6.519 x+7.210, R^{2}=0.990$ for dehydrated berries at $45 \% \mathrm{WL}$; and $y=-0.272 x^{2}+7.591 x$ $+11.399, R^{2}=0.984$ for dehydrated berries at $60 \% \mathrm{WL}$. After fourteen days of maceration, a plateau for $A_{280}$, representing total polyphenols index, was reached.

The spectrophotometric indices, monomeric and dimeric flavanol composition, and proanthocyanidin composition of Nebbiolo seeds, determined by chemical methods after sixteen days of maceration, are shown in Table 2 for winegrapes sampled at different WL values during the dehydration process. The results were expressed per seed weight in order to avoid the influence of the decrease in the berry weight during dehydration. In the present work, Pearson's correlation factors higher than $0.9(p<0.001)$ were obtained between the contents of the different phenolic compounds quantified in $\mathrm{mg} \mathrm{kg}^{-1}$ grape (Table S1) and the WL values. Instead, the seed weight remained practically constant during grape dehydration until reaching $60 \% \mathrm{WL}$, as can be observed in Table 1 .

Table 2 shows that the extractable contents of phenolic compounds in the seeds of fresh samples $(0 \% \mathrm{WL})$ agreed with those reported for the same winegrape variety growing in two different zones of North Italy (Rolle, Giacosa, Torchio, et al., 2013; Torchio, Giacosa, Río Segade, Gerbi, \& Rolle, 2014), with some few exceptions probably due to a vintage effect (Chira, Schmauch, Saucier, Fabre, \& Teissedre, 2009; Lorrain, Chira, \& Teissedre, 2011). Catechin $(C)$ was by far the main constituent of seed monomeric flavanols (64.0\%), followed by Epicathechin (EC) (35.6\%). Procyanidin $B_{1}$ was the major dimer $(53.5 \%)$ whereas procyanidin $\mathrm{B}_{2}$ occurred at slightly lower contents (46.5\%). Polymeric proanthocyanidins were the most abundant flavanols in the seeds. The terminal and extension units were mainly composed of $C$ and EC (76.6\% and $85.3 \%$, respectively) with a predominance of EC (41.3\% and 64.6\%, respectively). The Epicatechin 3-O-gallate (ECG) subunit occurred at significant contents in polymeric flavanols, representing a mean percentage of $23.4 \%$ and $14.6 \%$ of total content of terminal and extension units, respectively $\left(G_{\text {ter }}\right.$ and $G_{\text {ext }}$ in Table 2). Nevertheless, the $\mathrm{mDP}$ and $G$ values determined in the present study were higher than those reported in literature (Rolle, Giacosa, Torchio, et al., 2013). The longer maceration time of the seeds into the wine-like solution (16 days) may favor the extraction of large proanthocyanidins. Furthermore, some researchers observed an important vintage effect on mDP and $G$ (Chira et al., 2009; Lorrain et al., 2011). In any case, the mDP and $G$ values were in the range reported in other studies for different red winegrape varieties when a wine-like solution was used for the extraction of phenolic compounds from the seeds (Mattivi et al., 2009; Obreque-Slier, López-Solís, Castro-Ulloa, Romero-Díaz, \& PeñaNeira, 2012). The seeds were mainly rich in monomers and small oligomers, presenting a mDP value around 4 .

During grape postharvest dehydration, some variations in the extractable content of phenolic compounds in Nebbiolo seeds were observed (Table 2), although the predominant flavanols in fresh samples continued to be higher in dehydrated samples. When the berries lost $15 \%$ of their weight, the highest values of spectrophotometric indices $\left(A_{280}, \mathrm{TF}, \mathrm{PRO}\right.$ and FRV), extractable contents of monomeric ( $C$ and $\mathrm{EC}$ ) and dimeric (procyanidins $\mathrm{B}_{1}$ and $B_{2}$ ) flavanols, and mDP values were obtained. At $15 \% \mathrm{WL}$, most of these spectrophotometric indices were significantly higher than those found at $30 \%$ and $45 \% \mathrm{WL}$, and the extractable contents of monomeric and dimeric flavanols also differed significantly from those obtained at $45 \%$ and $60 \% \mathrm{WL}$. It is important to take into account that the percentages of galloylated subunits in both extension and total units (terminal and extension) decreased significantly during the postharvest dehydration process. Furthermore, the relative abundance of EC in the extension units increased significantly from $0 \%$ to $60 \% \mathrm{WL}$, achieving a value of $70.7 \%$ at the end of the dehydration process.

Some researchers showed a significant increase in the proanthocyanidin content of Pinot noir seeds (Moreno et al., 2008), and in the TF, PRO and FRV indices of Corvina seeds during postharvest dehydration when the results were expressed on a grape weight basis (Rolle, Giacosa, Río Segade, et al., 2013). Various studies reported similar proanthocyanidin contents and TP and TF indices in the seeds of dehydrated and fresh grapes of Pinot noir and Roscetto, respectively, when the results were expressed on the basis of the number of berries (Frangipane et al., 2012; Moreno et al., 2008). The number of berries is not variable as the grape weight during the dehydration process. Nevertheless, the FRV index increased progressively during the dehydration of Cesanese grapes when the results were expressed on the fresh and dry grape weight basis (Centioni et al., 2014). Therefore, genotype and dehydration conditions could affect the degradation of low molecular weight flavanols and the hydrolysis of larger oligomers, which overcome the concentration effect resulting from the water evaporation during dehydration (Rolle, Giacosa, Río Segade, et al., 2013). In agreement with a previous work, the mDP values of the seeds decreased as dehydration progressed from 15\% WL (Moreno et al., 2008), although the differences were not significant.

\subsection{Extractability of phenolic compounds from seeds}

With the aim of knowing if the variations in the extractable contents of phenolic compounds in the seeds could be the result of changes in their extractability and/or chemical reactions occurring during grape dehydration, the extraction yield was also evaluated (Table 3). The determination of the non-extractable fraction of phenolic compounds required the use of $70 \% \mathrm{v} / \mathrm{v}$ acetone in water as the extracting solvent. The intensive lignification of the medium integument in ripe seeds, which is waterproof and very hard, prevents phenolic compounds of the inner integument from being extracted during simulated maceration with the hydroalcoholic solution, whereas this extraction is possible using $70 \% \mathrm{v} / \mathrm{v}$ acetone in water (Bautista-Ortín et al., 2012).

The highest variations were found in polymeric proanthocyanidins, being represented by PRO $(+7.5 \%)$ and TPP $(+8.9 \%)$, whose extractability increased significantly during the postharvest dehydration process. The same pattern was also observed for TP $(+3.7 \%)$ and FRV (+4.8\%), which represent total phenols and low molecular weight flavanols, respectively. Nevertheless, the extractable contents of these phenolic compounds were not well related with their extractability. This could be due to the oxidation of flavanols extracted from the seeds belonging to dehydrated berries more than $15 \%$ of their initial weight, which could be then compensated by the concentration effect in highly dehydrated berries $(60 \% \mathrm{WL})$. Some authors pointed out that $20 \%$ WL is a critical point for metabolism during dehydration (Chkaiban et al., 2007; Nicoletti et al., 2013). 
Table 1

Standard parameters of Nebbiolo winegrapes sampled at different values of weight loss during dehydration. ${ }^{\mathrm{a}}$

\begin{tabular}{|c|c|c|c|c|c|c|}
\hline \multirow[t]{2}{*}{ Parameter $^{f}$} & \multicolumn{5}{|l|}{$W L^{f}$} & \multirow[t]{2}{*}{$\operatorname{Sign}^{\mathrm{d},}$} \\
\hline & $0 \%$ & $15 \%$ & $30 \%$ & $45 \%$ & $60 \%$ & \\
\hline TSS $\left({ }^{\circ} \text { Brix }\right)^{b}$ & $24.4 \pm 0.5 a$ & $28.3 \pm 0.1 b$ & $33.7 \pm 0.0 c$ & $43.8 \pm 0.8 \mathrm{~d}$ & $48.4 \pm 0.3 e$ & $* * *$ \\
\hline $\mathrm{pH}^{\mathrm{b}}$ & $3.06 \pm 0.01 a$ & $3.05 \pm 0.01 a$ & $3.20 \pm 0.01 b$ & $3.33 \pm 0.01 d$ & $3.26 \pm 0.01 c$ & $* * *$ \\
\hline $\mathrm{TA}\left(\mathrm{g} \mathrm{L}^{-1} \text { tartaric acid }\right)^{\mathrm{b}}$ & $7.41 \pm 0.13 a$ & $7.69 \pm 0.11 a$ & $7.22 \pm 0.08 a$ & $7.39 \pm 0.06 a$ & $8.51 \pm 0.05 b$ & *** \\
\hline Average seed weight $(\mathrm{mg})^{\mathrm{c}}$ & $33.0 \pm 0.4 b$ & $34.3 \pm 0.7 b$ & $32.8 \pm 0.9 b$ & $33.5 \pm 0.9 b$ & $30.7 \pm 0.7 a$ & $* *$ \\
\hline
\end{tabular}

a Data are expressed as mean value \pm standard deviation.

b $n=2$.

c Three replicates of 100 seeds.

d Different letters within the same row indicate significant differences according to the Tukey-b test $(p<0.05)$.

e Sign: **, and *** indicate significance at $p<0.01$, and $p<0.001$, respectively.

${ }^{\mathrm{f}}$ WL, weight loss; TSS, total soluble solids; TA, titratable acidity.

Table 2

Extractable phenolic composition of seeds from Nebbiolo winegrapes sampled at different values of weight loss during dehydration. ${ }^{a}$

\begin{tabular}{|c|c|c|c|c|c|c|}
\hline \multirow[t]{2}{*}{ Compound $^{\mathrm{d}}$} & \multicolumn{5}{|l|}{$\mathrm{WL}^{\mathrm{d}}$} & \multirow[t]{2}{*}{$\operatorname{Sign}^{\mathrm{b}, \mathrm{c}}$} \\
\hline & $0 \%$ & $15 \%$ & $30 \%$ & $45 \%$ & $60 \%$ & \\
\hline$A_{280}\left(\mathrm{~g}^{-1}\right.$ seed $)$ & $0.613 \pm 0.027 \mathrm{abc}$ & $0.677 \pm 0.027 c$ & $0.577 \pm 0.017 a$ & $0.605 \pm 0.035 \mathrm{ab}$ & $0.668 \pm 0.029 b c$ & $* *$ \\
\hline TP (mg (+)-catechin $g^{-1}$ seed) & $38.1 \pm 4.3$ & $39.8 \pm 0.6$ & $34.2 \pm 1.0$ & $34.8 \pm 2.9$ & $37.2 \pm 1.2$ & ns \\
\hline $\mathrm{TF}\left(\mathrm{mg}(+)\right.$-catechin $\mathrm{g}^{-1}$ seed $)$ & $26.3 \pm 1.8 \mathrm{ab}$ & $27.0 \pm 0.9 b$ & $23.4 \pm 0.5 a$ & $24.0 \pm 1.3 \mathrm{ab}$ & $26.1 \pm 1.0 \mathrm{ab}$ & $*$ \\
\hline PRO (mg cyanidin chloride $\mathrm{g}^{-1}$ seed) & $30.3 \pm 2.8 \mathrm{ab}$ & $32.4 \pm 1.5 b$ & $26.1 \pm 1.4 \mathrm{a}$ & $26.3 \pm 2.2 \mathrm{a}$ & $29.0 \pm 0.9 \mathrm{ab}$ & $* *$ \\
\hline FRV (mg (+)-catechin $\mathrm{g}^{-1}$ seed $)$ & $28.6 \pm 2.0 \mathrm{ab}$ & $31.1 \pm 0.5 b$ & $26.3 \pm 0.7 \mathrm{a}$ & $27.7 \pm 1.4 \mathrm{a}$ & $28.7 \pm 1.1 \mathrm{ab}$ & $* *$ \\
\hline $\mathrm{GA}\left(\mathrm{mg} \mathrm{g}^{-1}\right.$ seed $)$ & $0.380 \pm 0.015$ & $0.388 \pm 0.016$ & $0.375 \pm 0.017$ & $0.372 \pm 0.074$ & $0.358 \pm 0.037$ & ns \\
\hline $\mathrm{C}\left(\mathrm{mg} \mathrm{g}^{-1}\right.$ seed $)$ & $3.25 \pm 0.06 \mathrm{ab}$ & $3.56 \pm 0.23 b$ & $3.21 \pm 0.06 \mathrm{ab}$ & $2.97 \pm 0.04 a$ & $2.94 \pm 0.26 a$ & $* *$ \\
\hline $\mathrm{EC}\left(\mathrm{mg} \mathrm{g}^{-1}\right.$ seed $)$ & $1.81 \pm 0.03 \mathrm{bc}$ & $1.86 \pm 0.08 c$ & $1.72 \pm 0.01 b c$ & $1.64 \pm 0.03 \mathrm{ab}$ & $1.51 \pm 0.14 \mathrm{a}$ & $* *$ \\
\hline ECG $\left(\mathrm{mg} \mathrm{g}^{-1}\right.$ seed $)$ & $0.021 \pm 0.004 \mathrm{ab}$ & $0.012 \pm 0.008 a$ & $0.013 \pm 0.002 \mathrm{a}$ & $0.031 \pm 0.001 b$ & $0.026 \pm 0.005 b$ & $* *$ \\
\hline $\mathrm{B}_{1}\left(\mathrm{mg} \mathrm{g}^{-1}\right.$ seed $)$ & $0.963 \pm 0.031 \mathrm{abc}$ & $1.053 \pm 0.016 c$ & $0.980 \pm 0.016 b c$ & $0.880 \pm 0.034 a$ & $0.906 \pm 0.064 \mathrm{ab}$ & $* *$ \\
\hline $\mathrm{B}_{2}\left(\mathrm{mg} \mathrm{g}^{-1}\right.$ seed $)$ & $0.839 \pm 0.011 \mathrm{ab}$ & $0.905 \pm 0.012 b$ & $0.921 \pm 0.083 b$ & $0.811 \pm 0.028 \mathrm{ab}$ & $0.766 \pm 0.070 \mathrm{a}$ & $*$ \\
\hline $\mathrm{TM}\left(\mathrm{mg} \mathrm{g}^{-1}\right.$ seed $)$ & $5.08 \pm 0.08 b c$ & $5.43 \pm 0.30 c$ & $4.95 \pm 0.07 \mathrm{abc}$ & $4.64 \pm 0.01 \mathrm{ab}$ & $4.48 \pm 0.39 a$ & $* *$ \\
\hline $\mathrm{TD}\left(\mathrm{mg} \mathrm{g}^{-1}\right.$ seed $)$ & $1.80 \pm 0.03 \mathrm{ab}$ & $1.96 \pm 0.02 b$ & $1.90 \pm 0.10 \mathrm{~b}$ & $1.69 \pm 0.06 a$ & $1.67 \pm 0.13 a$ & $* *$ \\
\hline $\mathrm{TPP}\left(\mathrm{mg} \mathrm{g}^{-1}\right.$ seed $)$ & $21.9 \pm 1.6$ & $23.9 \pm 1.4$ & $20.4 \pm 1.4$ & $21.6 \pm 1.7$ & $22.3 \pm 1.5$ & ns \\
\hline $\mathrm{mDP}$ & $4.10 \pm 0.16 a b$ & $4.27 \pm 0.62 b$ & $4.03 \pm 0.17 a b$ & $3.88 \pm 0.02 \mathrm{ab}$ & $3.46 \pm 0.05 a$ & $*$ \\
\hline$G_{\text {ter }}(\%)$ & $23.4 \pm 1.3$ & $23.3 \pm 2.1$ & $21.4 \pm 0.3$ & $20.9 \pm 2.2$ & $19.5 \pm 1.1$ & ns \\
\hline$G_{\text {ext }}(\%)$ & $14.6 \pm 0.3 d$ & $13.4 \pm 0.2 \mathrm{ab}$ & $14.5 \pm 0.3 c d$ & $13.7 \pm 0.6 b c$ & $12.8 \pm 0.3 a$ & $* * *$ \\
\hline$G_{t}(\%)$ & $16.2 \pm 0.1 \mathrm{c}$ & $15.1 \pm 0.3 \mathrm{ab}$ & $15.7 \pm 0.3 b c$ & $15.1 \pm 0.8 \mathrm{ab}$ & $14.2 \pm 0.3 a$ & $* *$ \\
\hline
\end{tabular}

a Data are expressed as mean value \pm standard deviation $(n=3)$.

b Different letters within the same row indicate significant differences according to the Tukey-b test $(p<0.05)$.

c Sign: *,**,***, and ns indicate significance at $p<0.05, p<0.01, p<0.001$, and not significant, respectively.

d WL, weight loss; $A_{280}$, absorbance measured at $280 \mathrm{~nm}$; TP, total phenols; TF, total flavonoids; PRO, proanthocyanidins; FRV, flavanols reactive to vanillin; GA, gallic acid;

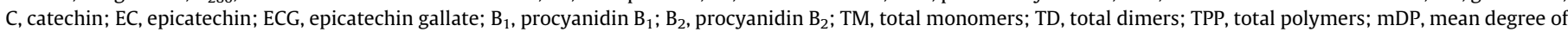
polymerization; $G_{\text {ter }}$, galloylation in terminal units; $G_{\text {ext }}$, galloylation in extension units; $G_{t}$, galloylation in all units.

Table 3

Extractability of phenolic compounds from seeds of Nebbiolo winegrapes sampled at different values of weight loss during dehydration. ${ }^{a}$

\begin{tabular}{|c|c|c|c|c|c|c|}
\hline \multirow[t]{2}{*}{ Compound $^{\mathrm{d}}$} & \multicolumn{5}{|l|}{$W_{L^{d}}$} & \multirow[t]{2}{*}{$\operatorname{Sign}^{\mathrm{b}, \mathrm{c}}$} \\
\hline & $0 \%$ & $15 \%$ & $30 \%$ & $45 \%$ & $60 \%$ & \\
\hline$A_{280}(\%)$ & $76.9 \pm 3.8$ & $80.6 \pm 3.3$ & $78.5 \pm 3.0$ & $81.6 \pm 2.3$ & $82.7 \pm 0.8$ & ns \\
\hline $\mathrm{TP}(\%)$ & $84.2 \pm 2.1 \mathrm{ab}$ & $85.1 \pm 2.3 \mathrm{ab}$ & $83.0 \pm 1.2 \mathrm{a}$ & $86.9 \pm 0.8 a b$ & $87.9 \pm 0.5 b$ & $*$ \\
\hline TF $(\%)$ & $71.5 \pm 5.5$ & $76.7 \pm 3.1$ & $74.3 \pm 4.1$ & $78.5 \pm 1.2$ & $80.4 \pm 0.2$ & ns \\
\hline PRO (\%) & $76.7 \pm 3.6 a$ & $79.6 \pm 2.3 \mathrm{ab}$ & $76.2 \pm 2.6 a$ & $82.0 \pm 0.8 \mathrm{ab}$ & $84.2 \pm 0.4 b$ & $* *$ \\
\hline FRV (\%) & $83.2 \pm 3.0 \mathrm{a}$ & $85.6 \pm 2.1 \mathrm{a}$ & $83.3 \pm 2.2 \mathrm{a}$ & $87.0 \pm 1.0 \mathrm{ab}$ & $88.0 \pm 0.7 b$ & $*$ \\
\hline GA (\%) & $97.6 \pm 0.3 b$ & $97.7 \pm 0.3 b$ & $97.6 \pm 0.5 b$ & $97.2 \pm 0.2 \mathrm{ab}$ & $96.7 \pm 0.2 \mathrm{a}$ & $*$ \\
\hline C (\%) & $97.2 \pm 0.3 b$ & $97.2 \pm 0.4 b$ & $97.0 \pm 0.5 b$ & $96.3 \pm 0.3 a b$ & $95.8 \pm 0.3 a$ & $* *$ \\
\hline EC (\%) & $95.2 \pm 0.7 b$ & $95.3 \pm 0.9 b$ & $94.9 \pm 0.8 b$ & $94.2 \pm 0.5 \mathrm{ab}$ & $93.5 \pm 0.3 a$ & $*$ \\
\hline ECG (\%) & $80.2 \pm 12.1$ & $61.2 \pm 31.1$ & $83.8 \pm 7.0$ & $82.2 \pm 4.5$ & $74.3 \pm 11.5$ & ns \\
\hline $\mathrm{B}_{1}(\%)$ & $97.2 \pm 0.8$ & $97.5 \pm 0.6$ & $97.3 \pm 0.7$ & $97.7 \pm 0.3$ & $97.6 \pm 0.2$ & ns \\
\hline $\mathrm{B}_{2}(\%)$ & $97.3 \pm 0.7$ & $98.2 \pm 0.4$ & $97.9 \pm 0.5$ & $98.1 \pm 0.2$ & $97.8 \pm 0.5$ & ns \\
\hline TM (\%) & $96.4 \pm 0.5 b$ & $96.5 \pm 0.5 b$ & $96.2 \pm 0.7 b$ & $95.4 \pm 0.4 \mathrm{ab}$ & $94.8 \pm 0.2 a$ & $* *$ \\
\hline TD (\%) & $97.3 \pm 0.7$ & $97.8 \pm 0.5$ & $97.6 \pm 0.6$ & $97.9 \pm 0.2$ & $97.7 \pm 0.3$ & ns \\
\hline ТPP (\%) & $75.5 \pm 3.8 \mathrm{a}$ & $80.3 \pm 2.0 \mathrm{ab}$ & $77.6 \pm 4.9 a b$ & $83.1 \pm 1.2 \mathrm{ab}$ & $84.4 \pm 1.4 b$ & $*$ \\
\hline
\end{tabular}

a Data are expressed as mean value \pm standard deviation $(n=3)$.

b Different letters within the same row indicate significant differences according to the Tukey-b test $(p<0.05)$.

c Sign: *,**, and ns indicate significance at $p<0.05, p<0.01$, and not significant, respectively.

d WL, weight loss; $A_{280}$, absorbance measured at $280 \mathrm{~nm}$; TP, total phenols; TF, total flavonoids; PRO, proanthocyanidins; FRV, flavanols reactive to vanillin; GA, gallic acid;

$C$, catechin; EC, epicatechin; ECG, epicatechin gallate; $B_{1}$, procyanidin $B_{1}$; $B_{2}$, procyanidin $B_{2}$; TM, total monomers; TD, total dimers; TPP, total polymers. 
Table 4

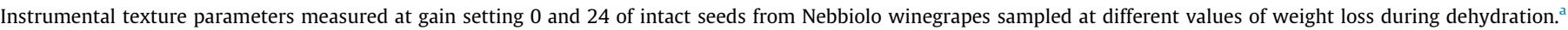

\begin{tabular}{|c|c|c|c|c|c|c|}
\hline \multirow[t]{2}{*}{ Parameter $^{d}$} & \multicolumn{5}{|l|}{$\mathrm{WL}^{\mathrm{d}}$} & \multirow[t]{2}{*}{$\operatorname{Sign}^{\mathrm{b}, \mathrm{c}}$} \\
\hline & $0 \%$ & $15 \%$ & $30 \%$ & $45 \%$ & $60 \%$ & \\
\hline \multicolumn{7}{|l|}{ Gain 0} \\
\hline Breakage (dB) & $88.3 \pm 16.2$ & $91.2 \pm 11.9$ & $89.3 \pm 13.8$ & $90.9 \pm 9.3$ & $94.1 \pm 10.5$ & ns \\
\hline Maximum (dB) & $94.8 \pm 6.8$ & $94.8 \pm 6.2$ & $93.5 \pm 6.6$ & $93.8 \pm 6.3$ & $96.6 \pm 6.3$ & ns \\
\hline \multicolumn{7}{|l|}{ Gain 24} \\
\hline$F_{s}(\mathrm{~N})$ & $44.9 \pm 7.8$ & $46.7 \pm 9.2$ & $43.7 \pm 9.1$ & $43.3 \pm 9.7$ & $42.6 \pm 7.5$ & ns \\
\hline$W_{s}(\mathrm{~mJ})$ & $9.19 \pm 2.53$ & $9.84 \pm 3.23$ & $8.60 \pm 2.96$ & $8.36 \pm 3.52$ & $8.05 \pm 2.44$ & ns \\
\hline$E_{s}\left(\mathrm{~N} \mathrm{~mm}^{-1}\right)$ & $100.8 \pm 19.4$ & $96.4 \pm 16.3$ & $96.4 \pm 13.4$ & $105.3 \pm 12.1$ & $106.7 \pm 16.2$ & ns \\
\hline $\mathrm{DI}_{\mathrm{s}}(\%)$ & $16.7 \pm 3.0 \mathrm{ab}$ & $17.9 \pm 3.8 b$ & $16.4 \pm 2.9 \mathrm{ab}$ & $15.5 \pm 3.0 \mathrm{a}$ & $14.8 \pm 2.6 a$ & $* *$ \\
\hline $\mathrm{AE}_{\mathrm{t}}(\mathrm{dB} \times \mathrm{mm})$ & $41.0 \pm 5.1 b$ & $45.2 \pm 6.5 c$ & $37.6 \pm 5.1 \mathrm{a}$ & $47.9 \pm 4.8 \mathrm{c}$ & $52.5 \pm 4.3 \mathrm{~d}$ & $* * *$ \\
\hline $\mathrm{LD}_{\mathrm{t}}$ & $3313 \pm 414 b$ & $3272 \pm 388 b$ & $2675 \pm 353 a$ & $3115 \pm 364 b$ & $3169 \pm 333 b$ & $* * *$ \\
\hline$N_{\mathrm{pk}>5 \mathrm{~dB}, \mathrm{t}}$ & $67.4 \pm 8.4 b$ & $69.1 \pm 10.8 b$ & $45.8 \pm 7.7 a$ & $65.6 \pm 9.1 b$ & $66.2 \pm 7.9 b$ & $* * *$ \\
\hline$N_{\mathrm{pk}>15 \mathrm{~dB}, \mathrm{t}}$ & $36.5 \pm 5.8 c$ & $37.9 \pm 7.4 \mathrm{c}$ & $26.4 \pm 4.0 \mathrm{a}$ & $31.3 \pm 6.4 b$ & $31.4 \pm 6.3 b$ & $* * *$ \\
\hline $\mathrm{AV}_{\mathrm{pk}>5 \mathrm{~dB}, \mathrm{t}}(\mathrm{dB})$ & $40.1 \pm 4.0 \mathrm{a}$ & $39.5 \pm 6.2 \mathrm{a}$ & $49.7 \pm 5.7 c$ & $42.9 \pm 5.0 \mathrm{ab}$ & $44.9 \pm 4.7 b$ & $* * *$ \\
\hline $\mathrm{AV}_{\mathrm{pk}>15 \mathrm{~dB}, \mathrm{t}}(\mathrm{dB})$ & $46.9 \pm 5.6 a$ & $45.1 \pm 8.2 \mathrm{a}$ & $55.9 \pm 5.8 b$ & $51.5 \pm 6.7 b$ & $54.3 \pm 7.3 b$ & $* * *$ \\
\hline
\end{tabular}

a Data are expressed as mean value \pm standard deviation $(n=30)$.

b Different letters within the same row indicate significant differences according to the Tukey-b test $(p<0.05)$.

c Sign: ${ }^{* *}, * * *$, and ns indicate significance at $p<0.01, p<0.001$, and not significant, respectively.

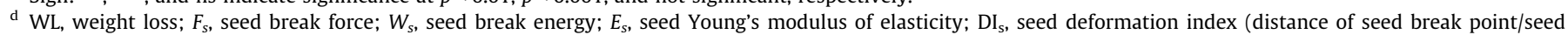

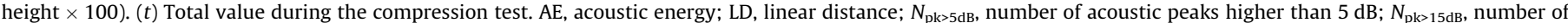

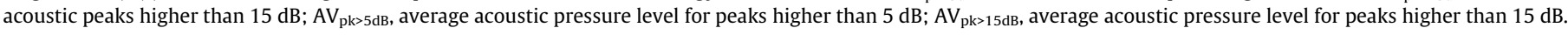

The extractability of individual monomeric flavanols (C and EC) and total monomers decreased significantly as grape dehydration progressed from $30 \%$ to $60 \%$ WL. In this case, the variations were small (less than $-2 \%$ ) probably due to the high extraction yield for all samples (higher than 93\%). The changes observed in the extractable contents of monomeric flavanols during the dehydration process (C, EC and TM; Table 2) might be the result of the variations in their extractability (Table 3). In fact, correlation coefficients higher than $0.67(p<0.01)$ were found. Otherwise, the extractability of dimeric flavanols (procyanidins $B_{1}$ and $B_{2}$, and total dimers) from the seeds was independent on berry dehydration.

\subsection{Instrumental texture parameters of seeds}

The effect of the postharvest dehydration process on the mechanical and acoustic parameters of the seeds was investigated (Table 4). In fresh berries, the mechanical properties $\left(F_{s}, W_{s}, E_{s}\right.$ and $D_{s}$ ) agreed with those reported in another study for Nebbiolo seeds (Torchio et al., 2014), however the acoustic properties were quite different from those previously published (Rolle, Giacosa, Torchio, et al., 2013). The acoustic characteristics of the seeds were more influenced than the mechanical attributes by the ripening effect, particularly $N_{\mathrm{pk}, \mathrm{t}}$ and $\mathrm{AV}_{\mathrm{pk}, \mathrm{t}}$ (Rolle, Giacosa, Torchio, et al., 2013; Torchio et al., 2014). This same pattern was also observed when seed hardness and cracking were evaluated by sensory descriptive analysis (Le Moigne, Maury, Bertrand, \& Jourjon, 2008; Letaief, Maury, Simoneaux, \& Siret, 2013).

As dehydration progressed, significant differences were found in the mechanical parameter $\mathrm{DI}_{\mathrm{s}}$ and the acoustic properties of the seeds measured at gain 24 . The values of $A E_{t}$ increased significantly during grape dehydration, with the exception of those corresponding to dehydrated berries at 30\% WL. Instead, the values of $D_{s}$ decreased progressively, with the exception of those dehydrated berries at $15 \%$ WL. Significantly lower values of $A E_{t}, L_{t}$ and $N_{\mathrm{pk}, \mathrm{t}}$, and higher ones of $\mathrm{AV}_{\mathrm{pk}, \mathrm{t}}$ were found in dehydrated berries at $30 \% \mathrm{WL}$. The values obtained of $A V_{\mathrm{pk}>15 \mathrm{~dB}, \mathrm{t}}$ for dehydrated berries at $30 \% \mathrm{WL}$ were not significantly different from those found for a grape dehydration of $45 \%$ and $60 \%$ WL. The outstanding acoustic behavior of the seeds from dehydrated berries at $15 \%$ or $30 \%$ WL could be due to tissue changes. Cadot et al. (2006) demonstrated that important anatomical, histological and histochemical changes occur in grape seeds during fruit development (from berry set to harvest), but no study has been performed until now on these changes in the seeds during grape dehydration. Furthermore, Costantini, Bellincontro, De Santis, Botondi, and Mencarelli (2006) pointed out that the first metabolic response of Malvasia grapes to postharvest water stress occurs up to $11.7 \% \mathrm{WL}$ and a second response beyond $19.5 \% \mathrm{WL}$. Other researchers confirmed that $20 \% \mathrm{WL}$ is a critical point for grape metabolism during dehydration (Chkaiban et al., 2007; Nicoletti et al., 2013). Therefore, histochemical changes in the seeds are expected together with grape metabolic changes during postharvest dehydration, which would justify the behavior of the acoustic properties of the seeds in dehydrated berries at $15 \%$ and $30 \%$ WL.

The experiments carried out in the food texture field pointed out that the number of acoustic peaks can be successfully used as an instrumental indicator of the sensory crispness/crunchiness of foods (Varela, Chen, Fiszman, \& Povey, 2006). The more acoustic peaks there are, the crispier/crunchier the product is (Saeleaw \& Schleining, 2011; Zdunek, Konopacka, \& Jesionkowska, 2010). Although this is not an essential enological feature, the crispness/ crunchiness changes in seeds from dehydrated grapes are unknown until now. According to Table 4, the fresh berries $(0 \%$ $\mathrm{WL}$ ) and the dehydrated berries at $15 \% \mathrm{WL}$ have the crunchiest seeds (the highest $N_{\mathrm{pk}, \mathrm{t}}$ values), whereas those dehydrated at $30 \%$ WL have the least crunchy seeds (the lowest $N_{\mathrm{pk}, \mathrm{t}}$ values). During grape dehydration, the hardness and elasticity of the seeds were practically constant because the mechanical parameters that define these textural properties $\left(F_{s}, W_{s}\right.$ and $\left.E_{s}\right)$ were not significantly different. This pattern could be a continuation of that occurred during the last stages of ripening, when a steady value of the mechanical attributes of the seeds was observed. Some researchers pointed out that most of the mechanical parameters of the seeds became steady three weeks after the end of véraison (Letaief et al., 2013).

In other studies regarding the on-vine dehydration process, the changes in the mechanical properties of the seeds were not significant up to the 55th day of withering (Rolle et al., 2009). Instead, the values of $\mathrm{AE}, N_{\mathrm{pk}}$ and $\mathrm{AV}_{\mathrm{pk}}$ increased significantly $(+38 \%$, $+16 \%$ and $+6 \%$, respectively) with the developmental changes occurred in the last stages of grape ripening (Rolle, Giacosa, et al., 2012). This strong variation in $\mathrm{AE}$ at the end of grape ripening could agree with the progressive increase in $A_{t}$ during grape 


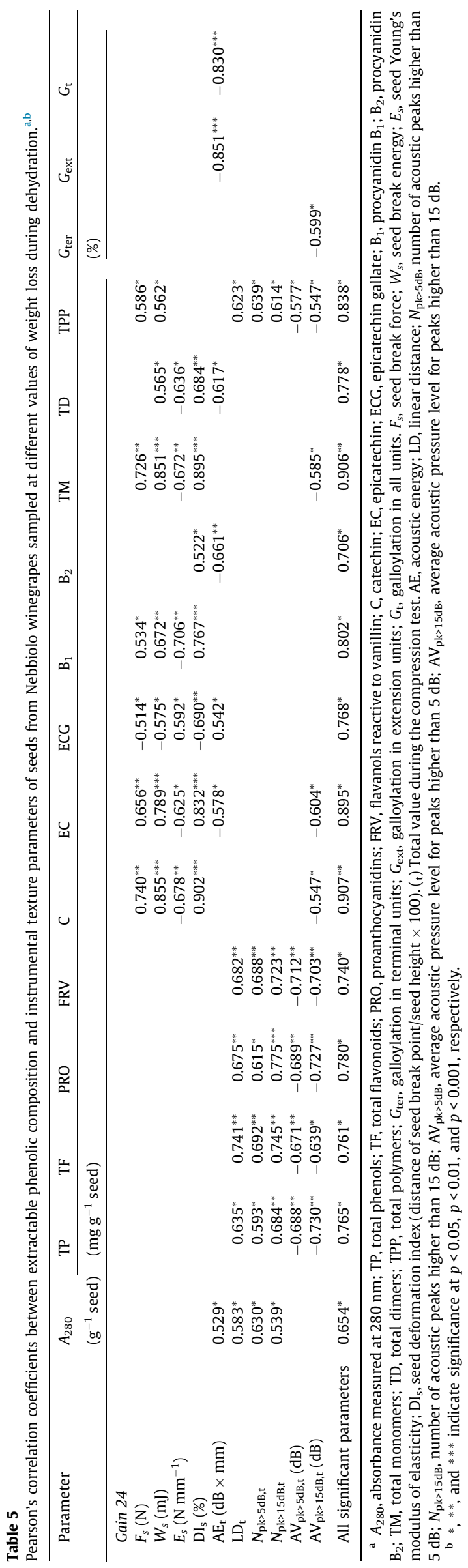

dehydration. In any case, it is important to take into account that the discriminating ability of the mechanical and acoustic properties of the seeds may depend on the operative conditions used during the compression test. For this reason, they were previously optimized (Torchio et al., 2012).

\subsection{Relationships between instrumental texture parameters and phenolic composition of seeds}

A correlation study was performed to evaluate if the mechanical and acoustic parameters of intact seeds could be useful in the prediction of the extractable content and extractability of phenolic compounds during the grape postharvest dehydration process. Tables 5 and 6 show the correlation coefficients and significance. The mechanical properties of the seeds were better correlated with the extractable content of individual flavanols than the acoustic ones. In fact, the four mechanical parameters $\left(F_{s}, W_{s}, E_{s}\right.$ and $\left.\mathrm{DI}_{s}\right)$ were significantly correlated with the extractable contents of $C$, EC, ECG, $B_{1}$, total monomers (as TM) and total dimers (as TD) $(R>0.51, p<0.05)$, with the exception of $F_{s}$ with TD. The highest coefficients corresponded to the correlations of the parameters $W_{s}$ and $\mathrm{DI}_{s}$ with the extractable contents of $\mathrm{C}, \mathrm{EC}$ and $\mathrm{TM}$ $(R>0.78, p<0.001)$. This agreed with the significant correlations found for fresh samples of winegrape varieties harvested at technological maturity from the same growing zone and sorted by density (Torchio et al., 2014). Specifically in this last study, the highest correlations of the extractable contents of C, EC, ECG, $B_{1}$, TM and TD were found with $W_{s}$ for many varieties, coefficients ranging from 0.521 to $0.574(p<0.001)$, whereas weaker correlations were observed with $\mathrm{DI}_{\mathrm{s}}(R=0.308-0.419, p<0.001)$. The prediction of monomeric flavanols is sensory important because these compounds are directly involved in bitterness (Peleg, Gacon, Schlich, \& Noble, 1999).

The acoustic parameter $A E_{t}$ was strongly correlated with the percentages of $G_{\text {ext }}$ and $G_{\text {total }}(R>0.83, p<0.001)$. Another study carried out on several red winegrape varieties, sampled in two growing zones at different ripening stages, showed significant correlations between the values of $\mathrm{AE}_{\mathrm{t}}$ and the percentages of $G_{\text {ter }}$ only when seed analyses were done at gain 0 (Rolle, Giacosa, Torchio, et al., 2013). The galloylation percentage is positively related with the perceived astringency (Ferrer-Gallego et al., 2010), and therefore its rapid estimation is of great relevance.

The remaining acoustic parameters $\left(\mathrm{LD}_{\mathrm{t}}, N_{\mathrm{pk}, \mathrm{t}}\right.$ and $\left.A V_{\mathrm{pk}, \mathrm{t}}\right)$ were significantly correlated with the spectrophotometric indices $\left(A_{280}\right.$, TP, TF, PRO and FRV $)(R>0.53, p<0.05)$, with the exception of $A V_{\mathrm{pk}, \mathrm{t}}$ with $A_{280}$. The acoustic parameter better correlated with TF, PRO and FRV indices was $N_{\mathrm{pk}>15 \mathrm{~dB}, \mathrm{t}}$ whereas $A V_{\mathrm{pk}>15 \mathrm{~dB}, \mathrm{t}}$ was with the TP index $(R>0.72, p<0.01)$. The above mentioned study also reported significant correlations between the values of $N_{\mathrm{pk}>5 \mathrm{~dB}, \mathrm{t}}$ and the TF index during grape ripening (Rolle, Giacosa, Torchio, et al., 2013). The correlations between the values of $N_{\mathrm{pk}>15 \mathrm{~dB}, \mathrm{t}}$ and the FRV index, as well as between those of $A V_{p k>15 d B, t}$ and the TP index, also were significant for Merlot seeds during grape ripening (Torchio et al., 2012). Furthermore, the extractable content of total polymers (as TPP) was significantly correlated with the parameters $F_{s}, W_{s}, \mathrm{LD}_{\mathrm{t}}, N_{\mathrm{pk}, \mathrm{t}}$ and $\mathrm{AV}_{\mathrm{pk}, \mathrm{t}}$ but the coefficients were relatively small $(R=0.55-0.64, p<0.05)$.

In the seeds, the FRV index is sensitive to the presence of monomeric flavanols and is partially related with the content of low molecular weight proanthocyanidins with a mDP value ranging from 2 to 4 (Mattivi et al., 2009). This spectrophotometric index provides relevant information on the main phenolic fraction released from intact seeds during winemaking. Instead, the PRO index is mainly related with the content of high molecular weight proanthocyanidins ( $>5$ units). Therefore, the first index is related to 
Table 6

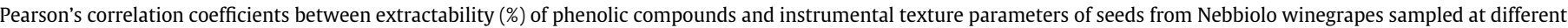
values of weight loss during dehydration.,

\begin{tabular}{|c|c|c|c|c|c|c|c|c|c|}
\hline & $\mathrm{TP}$ & $\mathrm{TF}$ & PRO & FRV & GA & C & $\mathrm{EC}$ & TM & TPP \\
\hline \multicolumn{10}{|l|}{ Gain 24} \\
\hline$W_{s}(\mathrm{~mJ})$ & & & & & & $0.538^{*}$ & & & \\
\hline$E_{s}\left(\mathrm{~N} \mathrm{~mm}^{-1}\right)$ & & & & & & $-0.550^{*}$ & & $-0.559^{*}$ & \\
\hline $\mathrm{DI}_{\mathrm{s}}(\%)$ & $-0.524^{*}$ & & $-0.527^{*}$ & & $0.554^{*}$ & $0.617^{*}$ & $0.522^{*}$ & $0.592^{*}$ & \\
\hline $\mathrm{AE}_{\mathrm{t}}(\mathrm{dB} \times \mathrm{mm})$ & $0.678^{* *}$ & $0.532^{*}$ & $0.749^{* *}$ & $0.635^{*}$ & $-0.756^{* *}$ & $-0.784^{* * *}$ & $-0.654^{* *}$ & $-0.755^{* *}$ & $0.617^{*}$ \\
\hline$N_{\mathrm{pk}>5 \mathrm{~dB}, \mathrm{t}}$ & $0.538^{*}$ & & & & & & & & \\
\hline All significant parameters & $0.780^{*}$ & & $0.777^{* *}$ & & $0.792^{* *}$ & $0.839^{*}$ & $0.701^{*}$ & $0.805^{* *}$ & \\
\hline
\end{tabular}

a TP, total phenols; TF, total flavonoids; PRO, proanthocyanidins; FRV, flavanols reactive to vanillin; GA, gallic acid; C, catechin; EC, epicatechin; TM, total monomers; TPP,

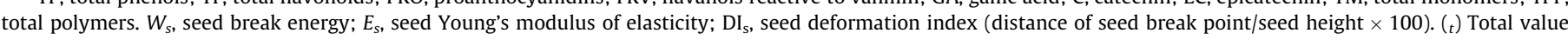
during the compression test. AE, acoustic energy; $N_{\mathrm{pk}>5 \mathrm{~dB}}$, number of acoustic peaks higher than $5 \mathrm{~dB}$.

$\mathrm{b} *, * *$, and $* * *$ indicate significance at $p<0.05, p<0.01$, and $p<0.001$, respectively.

bitter flavanols whereas the last one is more sensitive to astringent flavanols (Peleg et al., 1999).

Regarding extractability from the seeds (Table 6), the most significant and strongest correlations corresponded to the values of the parameter $\mathrm{AE}_{\mathrm{t}}$ with $\mathrm{GA}, \mathrm{C}, \mathrm{EC}, \mathrm{TM}$, TP and PRO $(R>0.65$, $p<0.01)$, the highest coefficient being found for $C(R=0.784$, $p<0.001)$. Other texture attributes were significantly correlated with the same chemical parameters, but the coefficients were smaller. Finally, the parameter $\mathrm{AE}_{\mathrm{t}}$ was also significantly correlated with the extractability of TPP, TF and FRV, but the correlations were weak $(R=0.53-0.64, p<0.05)$. The acoustic pressure level at the breakage and maximum acoustic pressure level were not significantly correlated with the phenolic composition of the seeds, and $\mathrm{mDP}$ was not significantly correlated with the mechanical and acoustic attributes of the seeds (Tables 5 and 6).

In an attempt to improve the correlations and to increase the reliability of the relationships obtained, multivariate linear regressions were carried out using the mechanical and acoustic parameters significantly related with each chemical parameter (Tables 5 and 6). In general, the correlation coefficients increased when multivariate regressions were used, but this increase was more relevant for the extractable content of TD $(R=0.78$, $p<0.05)$ and TPP $(R=0.84, p<0.05)$, as well as for the extractability of TP $(R=0.78, p<0.05)$. Therefore, more reliable predictions for these three parameters require the use of multivariate models.

\section{Conclusions}

During grape postharvest dehydration, significant variations were observed in the mechanical and acoustic properties of the seeds, which were consistent with those expected from extended ripening. These variations were related with changes in the extractable content and extractability of phenolic compounds. Therefore, some instrumental texture parameters could be used as possible predictors of the phenolic composition of the seeds during dehydration. This should be of great concern in winemaking of dehydrated grapes to decide on the optimal weight loss according to the wine type to produce. In fact, the extractable content and extractability of monomeric flavanols and proanthocyanidins, as well as the galloylation percentage of flavanols, might be estimated easily and quickly from the mechanical and acoustic properties of intact seeds for assessing and managing the extraction of phenolic compounds during the winemaking process of berries with different levels of dehydration. This aspect is particularly important for winegrape cultivars with a high richness in seed flavanols, such as the Nebbiolo cultivar, because the flavanolic composition of the seeds is related with wine bitterness and astringency. Once verified the predictive ability of the mechanical and acoustic properties, the study could be extended to other growing zones, vintages and varieties with the aim of developing reliable predictive models for the phenolic composition of the seeds during grape dehydration.

\section{Acknowledgment}

Authors from University of Salamanca thank the Spanish MICINN (Project ref. AGL2014-58486-C2-1-R) for financial support.

\section{Appendix A. Supplementary material}

Supplementary data associated with this article can be found, in the online version, at http://dx.doi.org/10.1016/j.foodchem.2015. 12.072 .

\section{References}

Barbanti, D., Mora, B., Ferrarini, R., Tornielli, G. B., \& Cipriani, M. (2008). Effect of various thermo-hygrometric conditions on the withering kinetics of grapes used for the production of "Amarone" and "Recioto" wines. Journal of Food Engineering, 85, 350-358.

Bautista-Ortín, A. B., Rodríguez-Rodríguez, P., Gil-Muñoz, R., Jiménez-Pascual, E., Busse-Valverde, N., Martínez-Cutillas, A., ... Gómez-Plaza, E. (2012). Influence of berry ripeness on concentration, qualitative composition and extractability of grape seed tannins. Australian Journal of Grape and Wine Research, 18, 123-130.

Bonghi, C., Rizzini, F. M., Gambuti, A., Moio, L., Chkaiban, L., \& Tonutti, P. (2012) Phenol compound metabolism and gene expression in the skin of wine grape (Vitis vinifera L.) berries subjected to partial postharvest dehydration. Postharvest Biology and Technology, 67, 102-109.

Cadot, Y., Miñana-Castelló, M. T., \& Chevalier, M. (2006). Anatomical, histological, and histochemical changes in grape seeds from Vitis vinifera L cv Cabernet franc during fruit development. Journal of Agricultural and Food Chemistry, 54, 9206-9215.

Centioni, L., Tiberi, D., Pietromarchi, P., Bellincontro, A., \& Mencarelli, F. (2014) Effect of postharvest dehydration on content of volatile organic compounds in the epicarp of Cesanese grape berry. American Journal of Enology and Viticulture $65,333-340$

Chira, K., Schmauch, G., Saucier, C., Fabre, S., \& Teissedre, P.-L. (2009). Grape variety effect on proanthocyanidin composition and sensory perception of skin and seed tannin extracts from Bordeaux wine grapes (Cabernet Sauvignon and Merlot) for two consecutive vintages (2006 and 2007). Journal of Agricultural and Food Chemistry, 57, 545-553.

Chkaiban, L., Botondi, R., Bellincontro, A., De Santis, D., Kefalas, P., \& Mencarelli, F (2007). Influence of postharvest water stress on lipoxygenase and alcoho dehydrogenase activities, and on the composition of some volatile compounds of Gewürztraminer grapes dehydrated under controlled and uncontrolled thermohygrometric conditions. Australian Journal of Grape and Wine Research $13,142-149$.

Costantini, V., Bellincontro, A., De Santis, D., Botondi, R., \& Mencarelli, F. (2006). Metabolic changes of Malvasia grapes for wine production during postharvest drying. Journal of Agricultural and Food Chemistry, 54, 3334-3340.

Downey, M. O., Harvey, J. S., \& Robinson, S. P. (2003). Analysis of tannins in seeds and skins of Shiraz grapes throughout berry development. Australian Journal of Grape and Wine Research, 9, 15-27.

Ferrer-Gallego, R., García-Marino, M., Hernández-Hierro, J. M., Rivas-Gonzalo, J. C., \& Escribano-Bailón, M. T. (2010). Statistical correlation between flavanolic composition, colour and sensorial parameters in grape seed during ripening. Analytica Chimica Acta, 660, 22-28.

Frangipane, M. T., Torresi, S., De Santis, D., \& Massantini, R. (2012). Effect of drying process in chamber at controlled temperature on the grape phenolic compounds. Italian Journal of Food Science, 24, 26-31. 
Kennedy, J. A., \& Jones, G. P. (2001). Analysis of proanthocyanidin cleavage products following acid-catalysis in the presence of excess phloroglucinol. Journal of Agricultural and Food Chemistry, 49, 1740-1746.

Kennedy, J. A., Matthews, M. A., \& Waterhouse, A. L. (2000). Changes in grape seed polyphenols during fruit ripening. Phytochemistry, 55, 77-85.

Le Moigne, M., Maury, C., Bertrand, D., \& Jourjon, F. (2008). Sensory and instrumental characterisation of Cabernet Franc grapes according to ripening stages and growing location. Food Quality and Preference, 19, 220-231.

Letaief, H., Maury, C., Simoneaux, R., \& Siret, R. (2013). Sensory and instrumental texture measurements for assessing grape seed parameters during fruit development. Journal of the Science of Food and Agriculture, 93, 2531-2540.

Lorrain, B., Chira, K., \& Teissedre, P.-L. (2011). Phenolic composition of Merlot and Cabernet-Sauvignon grapes from Bordeaux vineyard for the 2009-vintage: Comparison to 2006, 2007 and 2008 vintages. Food Chemistry, 126, 1991-1999.

Mattivi, F., Vrhovsek, U., Masuero, D., \& Trainotti, D. (2009). Differences in the amount and structure of extractable skin and seed tannins amongst red grape varieties. Australian Journal of Grape and Wine Research, 15, 27-35.

Mencarelli, F., Bellincontro, A., Nicoletti, I., Cirilli, M., Muleo, R., \& Corradini, D. (2010). Chemical and biochemical change of healthy phenolic fractions in winegrape by means of postharvest dehydration. Journal of Agricultural and Food Chemistry, 58, 7557-7564.

Mencarelli, F., \& Tonutti, P. (2013). Sweet, Reinforced and Fortified Wines: Grape Biochemistry, Technology and Vinification. Wiley-Blackwell, A John Wiley \& Sons, Ltd., Publication.

Moreno, J. J., Cerpa-Calderón, F., Cohen, S. D., Fang, Y., Qian, M., \& Kennedy, J. A. (2008). Effect of postharvest dehydration on the composition of Pinot noir grapes (Vitis vinifera L.) and wine. Food Chemistry, 109, 755-762.

Nicoletti, I., Bellincontro, A., De Rossi, A., De Sanctis, F., Tiberi, D., Pietromarchi, P., .. Mencarelli, F. (2013). Postharvest dehydration of Nebbiolo grapes grown at altitude is affected by time of defoliation. Australian Journal of Grape and Wine Research, 19, 358-368.

Obreque-Slier, E., López-Solís, R., Castro-Ulloa, L., Romero-Díaz, C., \& Peña-Neira, A (2012). Phenolic composition and physicochemical parameters of Carménère, Cabernet Sauvignon, Merlot and Cabernet Franc grape seeds (Vitis vinifera L.) during ripening. LWT Food Science and Technology, 48, 134-141.

Organisation Internationale de la Vigne et du Vin (2008). Recueil international des méthodes d'analyse des vins et des moûts. Paris: Organisation Internationale de la Vigne et du Vin.

Peleg, H., Gacon, K., Schlich, P., \& Noble, A. C. (1999). Bitterness and astringency of flavan-3-ol monomers, dimers and trimmers. Journal of the Science of Food and Agriculture, 79, 1123-1128.

Rolle, L., Giacosa, S., Río Segade, S., Ferrarini, R., Torchio, F., \& Gerbi, V. (2013). Influence of different thermohygrometric conditions on changes in instrumental texture properties and phenolic composition during postharvest withering of 'Corvina' winegrapes (Vitis vinifera L.). Drying Technology, 31, 549-564.

Rolle, L., Giacosa, S., Torchio, F., Perenzoni, D., Río Segade, S., Gerbi, V. \& Mattivi, F. (2013). Use of instrumental acoustic parameters of winegrape seeds as possible predictors of extractable phenolic compounds. Journal of Agricultural and Food Chemistry, 61, 8752-8764.
Rolle, L., Giacosa, S., Torchio, F., \& Río Segade, S. (2012). Changes in acoustic and mechanical properties of Cabernet Sauvignon seeds during ripening. American Journal of Enology and Viticulture, 63, 413-418.

Rolle, L., Torchio, F., Giacosa, S., \& Gerbi, V. (2009). Modifications of mechanical characteristics and phenolic composition in berry skins and seeds of Mondeuse winegrapes throughout the on-vine drying process. Journal of the Science of Food and Agriculture, 89, 1973-1980.

Rolle, L., Torchio, F., Giacosa, S., Río Segade, S., Cagnasso, E., \& Gerbi, V. (2012) Assessment of physicochemical differences in Nebbiolo grape berries from different production areas and sorted by flotation. American Journal of Enology and Viticulture, 63, 195-204.

Rolle, L., Torchio, F., Lorrain, B., Giacosa, S., Río Segade, S., Cagnasso, E. ... Teissedre, P.-L. (2012). Rapid methods for the evaluation of total phenol content and extractability in intact grape seeds of Cabernet-Sauvignon: Instrumental mechanical properties and FT-NIR spectrum. Journal International des Sciences de la Vigne et du Vin, 46, 29-40.

Saeleaw, M., \& Schleining, G. (2011). A review: Crispness in dry foods and quality measurements based on acoustic-mechanical destructive techniques. Journal of Food Engineering, 105, 387-399.

Santonico, M., Bellincontro, A., De Santis, D., Di Natale, C., \& Mencarelli, F. (2010). Electronic nose to study postharvest dehydration of wine grapes. Food Chemistry, 121, 789-796.

Serratosa, M. P., Lopez-Toledano, A., Merida, J., \& Medina, M. (2008). Changes in color and phenolic compounds during the raisining of grape cv. Pedro Ximenez. Journal of Agricultural and Food Chemistry, 56, 2810-2816.

Serratosa, M. P., Marquez, A., Moyano, L., Zea, L., \& Merida, J. (2014). Chemical and morphological characterization of Chardonnay and Gewürztraminer grapes and changes during chamber-drying under controlled conditions. Food Chemistry, $159,128-136$.

Torchio, F., Giacosa, S., Río Segade, S., Gerbi, V., \& Rolle, L. (2014). Berry heterogeneity as a possible factor affecting the potential of seed mechanical properties to classify wine grape varieties and estimate flavanol release in wine-like solution. South African Journal of Enology and Viticulture, 35, 20-42.

Torchio, F., Giacosa, S., Río Segade, S., Mattivi, F., Gerbi, V., \& Rolle, L. (2012). Optimization of a method based on the simultaneous measurement of acoustic and mechanical properties of winegrape seeds for the determination of the ripening stage. Journal of Agricultural and Food Chemistry, 60, 9006-9016.

Torchio, F., Río Segade, S., Giacosa, S., Gerbi, V., \& Rolle, L. (2013). Effect of growing zone and vintage on the prediction of extractable flavanols in winegrape seeds by a FT-NIR method. Journal of Agricultural and Food Chemistry, 61, 9076-9088.

Torchio, F., Urcan, D. E., Lin, L., Gerbi, V., Giacosa, S., Río Segade, S., ... Rolle, L. (2016). Influence of different withering conditions on phenolic composition of Avanà, Chatus and Nebbiolo grapes for the production of 'Reinforced' wines. Food Chemistry, 194, 247-256.

Varela, P., Chen, J., Fiszman, S., \& Povey, M. J. W. (2006). Crispness assessment of roasted almonds by an integrated approach to texture description: Texture, acoustics, sensory and structure. Journal of Chemometrics, 20, 311-320.

Zdunek, A., Konopacka, D., \& Jesionkowska, K. (2010). Crispness and crunchiness judgment of apples based on contact acoustic emission. Journal of Texture Studies, 41, 75-91. 